\title{
A new species of Escallonia (Escalloniaceae) from the inter- Andean tropical dry forests of Bolivia
}

\author{
Felipe Zapata ${ }^{\text {Corresp.. }} 1$, Daniel Villarroel ${ }^{2,3}$ \\ 1 Department of Ecology and Evolutionary Biology, University of California, Los Angeles, Los Angeles, United States \\ 2 Fundación Amigos de la Naturaleza, Santa Cruz, Bolivia \\ 3 Universidad Autonoma Gabriel René, Museo de Historia Natural Noel Kempff Mercado, Santa Cruz, Bolivia \\ Corresponding Author: Felipe Zapata \\ Email address: fzapata@ucla.edu
}

Over the last two decades, renewed fieldwork in poorly explored areas of the tropical Andes has dramatically increased the comparative material available to study patterns of inter- and intraspecific variation in tropical plants. In the course of a comprehensive study of the genus Escallonia, we found a group of specimens with decumbent branching, small narrowly elliptic leaves, inflorescences with up to three flowers, and flowers with red petals. This unique combination of traits was not present in any known species of the genus. To evaluate the hypothesis that these specimens belonged to a new species, we assessed whether morphological variation between the putative new species and all currently known Escallonia species was discontinuous. The lack of overlap in tolerance regions for vegetative and reproductive traits combined with differences in habit, habitat, and geographic distribution supported the hypothesis of the new species, which we named Escallonia harrisii. The new species grows in sandstone inter-Andean ridges and cliffs covered with dry forest, mostly on steep slopes between 1,300 - 2,200 m in southern Bolivia. It is readily distinct in overall leaf and flower morphology from other Escallonia species in the region, even though it does not grow in sympatry with other species. Because E. harrisii is locally common it may not be threated at present, but due to its restricted geographic distribution and the multiple threats of the tropical dry forests it could become potentially vulnerable. 
- A new species of Escallonia (Escalloniaceae) from the inter-Andean tropical dry forests of Bolivia

${ }_{4}$ Felipe Zapata ${ }^{1}$ and Daniel Villarroel ${ }^{2,3}$

\author{
${ }^{1}$ Department of Ecology and Evolutionary Biology, University of California, Los \\ Angeles, Los Angeles, California, U.S.A. \\ ${ }^{2}$ Fundación Amigos de la Naturaleza, Santa Cruz, Bolivia \\ ${ }^{3}$ Museo de Historia Natural Noel Kempff Mercado, Universidad Autónoma Gabriel René \\ Moreno, Santa Cruz, Bolivia \\ Corresponding author: \\ Felipe Zapata ${ }^{1}$ \\ Email address: fzapata@ucla.edu
}

\begin{abstract}
14 Over the last two decades, renewed fieldwork in poorly explored areas of the tropical Andes has dramatically increased the comparative material available to study patterns of inter- and intraspecific variation in tropical plants. In the course of a comprehensive study of the genus Escallonia, we found a group of specimens with decumbent branching, small narrowly elliptic leaves, inflorescences with up to three flowers, and flowers with red petals. This unique combination of traits was not present in any known species of the genus. To evaluate the hypothesis that these specimens belonged to a new species, we assessed whether morphological variation between the putative new species and all currently known Escallonia species was discontinuous. The lack of overlap in tolerance regions for vegetative and reproductive traits combined with differences in habit, habitat, and geographic distribution supported the hypothesis of the new species, which we named Escallonia harrisii. The new species grows in sandstone inter-Andean ridges and cliffs covered with dry forest, mostly on steep slopes between 1,300 - 2,200 $\mathrm{m}$ in southern Bolivia. It is readily distinct in overall leaf and flower morphology from other Escallonia species in the region, even though it does not grow in sympatry with other species. Because $E$. harrisii is locally common it may not be threated at present, but due to its restricted geographic distribution and the multiple threats of the tropical dry forests it could become potentially vulnerable.
\end{abstract}

\title{
INTRODUCTION
}

The tropical Andes harbor an exceptional concentration of endemic plant species and are considered one of the hottest global biodiversity hotspots (Myers et al., 2000). Patterns of species richness and endemicity in these mountains vary with elevation as a result of the evolutionary history of resident lineages. The low elevation tropical dry forest stands out as a remarkable biome that includes more species-poor but endemic-rich clades than other Andean biomes due to the persistence of old lineages that have diversified over the last 20 my. (Särkinen et al., 2011). Unfortunately, these evolutionarily unique forests are highly threatened (Banda-R et al., 2016). Therefore discovering, describing, and documenting their biodiversity is of significant interest to evolutionary and conservation biologists alike.

Escallonia Mutis ex L.f. (Escalloniaceae) is a morphologically and ecologically diverse genus of shrubs and small trees widely distributed in the neotropical mountains (Zapata, 2013; Sede and Denham, 2018). It is characterized by its sympodial growth with distinctive long- and short-shoot construction. The leaves are always simple, spiral, and with serrate margins. Flowers are borne singly or in inflorescences of few to many flowers. The flowers are always pentamerous, with free petals at maturity and inferior ovaries. There is an intrastaminal nectary disk, and always a characteristic large discoid stigma. All Escallonia species have bilocular septicidal capsules enclosing about 100 minute seeds. The species examined so far show the same chromosome morphology and base number (n=12) (Zielinski, 1955; Sanders et al., 1983; 
Hanson et al., 2003). Some species have a long history in horticulture and are widely used as ornamentals (Sleumer, 1968; Denaeghel et al., 2018).

Escallonia, with 39 species, is one the most species-rich genera in the Escalloniaceae (APG, 2016). Although relationships within Escalloniaceae and between Escalloniaceae and other Campanulids are not fully resolved (Tank and Donoghue, 2010; Beaulieu and O'Meara, 2018), the monophyly of Escallonia is strongly supported (Sede et al., 2013; Zapata, 2013). Most Escallonia species are distributed along the Andes, from northern Venezuela to southern Argentina, and the mountains of Costa Rica. Some species are restricted to the mountains of southeastern Brazil, and one species occurs in Juan Fernández Island. Most species have comparatively broad geographic ranges, and only few species are extremely narrow endemics (Sleumer, 1968). The phylogeny of Escallonia shows considerable phylogenetic geographic structure with major clades restricted to geographic regions (Zapata, 2013). This suggests that old divergences are associated with geographic isolation and that recent divergences are associated with bioclimatic differentiation along elevation gradients within geographic regions.

Historically, Escallonia has been relatively well-collected in some areas such as the southern Andes (Kausel, 1953; Sleumer, 1968; Sede and Denham, 2018). Renewed field exploration in poorly-known and highly threatened regions of the tropical Andes has made available new comparative material to study broad patterns of variation and reassess species boundaries in the genus. In this study, we present and describe a new species of Escallonia restricted to the dry forests of southern Bolivia. We include a detailed description and illustration, and a discussion of the eco-phenotypic differences between the new species and other species that occur in the region.

\section{MATERIALS \& METHODS}

\section{Species concept}

In the present study, we follow the general lineage species concept (de Queiroz, 1998), which proposes that species are independently evolving segments of population-level lineages and that any evidence of lineage separation (i.e., distinct morphology, differences in ecological niche, monophyly of alleles) is sufficient to infer the existence of separate species (De Queiroz, 2007). Here, we assess discontinuities in continuous morphological traits using the approach proposed by Zapata and Jiménez (2012), in combination with differences in habit, habitat and geographic distribution.

\section{Taxon sampling}

A total of 809 herbarium specimens from all species of Escallonia and the new species were included in this study. Escallonia salicifolia Mattf. was not included here because only two specimens were available and the method used in this study requires a sample size larger than three (Zapata and Jiménez, 2012). Voucher information for all specimens is available in a git repository at http://github.com/zapataf/ms_eharrisii

\section{Morphological measurements}

Because the new species differs from other Escallonia species in overall leaf shape and flower number, we tested the hypothesis that the new species boundary exists in the morphological spaces defined by these traits. To quantify leaf shape, we measured leaf length and width, and we counted the number of flowers per inflorescence in all specimens. On each specimen, we recorded leaf measurements from three different leaves and then averaged to generate mean leaf measurements. We counted flower number on one inflorescence per specimen.

\section{Morphological discontinuities}

We assessed morphological discontinuities in leaf shape and flower number between the new species and all Escallonia species using the method of Zapata and Jiménez (2012). This pairwise method assesses whether the overlap of morphological values is below a given threshold to indicate a discontinuity, and thus support a species boundary. To determine morphological overlap, this method estimates the overlap of statistical tolerance regions in the morphological space defined by measurements of two species. Statistical tolerance regions correspond to the regions estimated with statistical confidence $\gamma$ that encompass a proportion $\beta$ of a population (i.e., a species). In this study, we used statistical confidence $\gamma=0.90$ and a threshold 0.15 . Therefore, we inferred a morphological discontinuity when proportions $\beta \geq 0.85$ (one minus threshold) of each species in a pairwise comparison did not overlap. For leaf shape, 
we estimated the statistical tolerance regions for each species sharing a single point along the ridgeline manifold. The ridgeline manifold is the curve that includes all the critical points (maxima, minima, and saddles) of the bivariate normal mixture describing variation in leaf shape implied by each pairwise comparison. For flower number, we estimated one-tailed statistical tolerance regions describing variation in flower number implied by each pairwise comparison. All analyses were carried out in R 3.5.0 ( $\mathrm{R}$ Core Team, 2016); source code and the data used in these analyses are available in a git repository at http://github.com/zapataf/ms_eharrisii

The electronic version of this article in Portable Document Format (PDF) will represent a published work according to the International Code of Nomenclature for algae, fungi, and plants (ICN), and hence the new names contained in the electronic version are effectively published under that Code from the electronic edition alone. In addition, new names contained in this work which have been issued with identifiers by IPNI will eventually be made available to the Global Names Index. The IPNI LSIDs can be resolved and the associated information viewed through any standard web browser by appending the LSID contained in this publication to the prefix "http://ipni.org/". The online version of this work is archived and available from the following digital repositories: PeerJ, PubMed Central, and CLOCKSS.

\section{RESULTS \& DISCUSSION}

\section{Discontinuity in leaf morphology}

The new species has small narrowly elliptic leaves (14.5-19.7 x 1.6-3.7 mm), which are uncommon in Escallonia (Figure 1). The weight of the evidence supporting a morphological discontinuity in leaf morphology is strong between the new species and the following 20 species: E. angustifolia C. Presl, E. bifida Link \& Otto, E. chlorophylla Cham. \& Schltdl., E. farinacea A. St.-Hil., E. herrerae Mattf., E. hispida (Vell.) Sleumer, E. illinita C. Presl, E. laevis (Vell.) Sleumer, E. micrantha Mattf., E. millegrana Griseb., E. myrtoidea Bertero ex DC., E. obtusissima A. St.-Hil., E. paniculata (Ruiz \& Pav.) Roem. \& Schult., E. pendula (Ruiz \& Pav.) Pers., E. petrophila Rambo \& Sleumer, E. piurensis Mattf., E. pulverulenta (Ruiz \& Pav.) Pers., E. reticulata Sleumer, E. revoluta (Ruiz \& Pav.) Pers., and E. schreiteri Sleumer (Figure 2). These results support the hypothesis of a species boundary between the new species and 20 currently known Escallonia species.

\section{Discontinuity in flower number}

The new species has inflorescences with up to three flowers, which are uncommon in Escallonia (Figure 3 ). There is support for a morphological discontinuity in flower number between the new species and 30 species, 19 of which are also separated by a discontinuity in leaf morphology (see above, all species except $E$. petrophila). The remaining 11 species separated only by a morphological discontinuity in flower number are: E. alpina Poepp. ex DC., E. cordobensis (Kuntze) Hosseus, E. discolor Vent., E. florida Poepp. ex DC., E. hypoglauca Herzog, E. leucantha J. Rémy, E. megapotamica Spreng., E. resinosa (Ruiz \& Pav.) Pers, E. rubra (Ruiz \& Pav.) Pers., E. tucumanensis Hosseus, and E. virgata (Ruiz \& Pav.) Pers. (Figure 4). These results support the hypothesis of a species boundary between the new species and 30 currently known Escallonia species.

\section{Support for the new species boundary}

Taken together, the results described above show there is evidence supporting a species boundary between the new species and 31 currently known Escallonia species. In most cases the new species boundary spans differences in both leaf and flower traits (19 species). In other cases, the species boundary is supported with evidence from one of the traits (12 species). This is consistent with the species concept we apply in this study (De Queiroz, 2007). For instance, E. micrantha and the new species differ in both leaf shape and flower number, whereas $E$. florida and the new species differ in flower number but are broadly similar in leaf shape (Figure 2, Figure 4). No material for DNA sequencing was available to place the new species in the Escallonia phylogeny, therefore it is not possible to discern whether morphological similarities between the new species and other species reflect convergent evolution or recent divergence with little differentiation. 


\section{Lack of support for morphological discontinuities, differences in habit and habitat, and alternative explanations}

The weight of the evidence supporting a morphological discontinuity between the new species and the following seven species was weak: E. callcottiae Hook. \& Arn., E. gayana Acevedo \& Kausel, E. ledifolia Sleumer, E. myrtilloides L. f., E. polifolia Hook., E. rosea Griseb., and E. serrata Sm.. There are three non-exclusive reasons to explain why this result does not undermine the hypothesis of a species boundary between the new species and any of these seven species: i) Habit and habitat. E. myrtilloides, E. polifolia, E. rosea, E. serrata, and the new species all differ in habit and habitat. E. myrtilloides includes small trees with thick branches, obovate glabrous leaves, and it is restricted to the páramos and jalcas in the tropical Andes above 2,600 m. E. polifolia includes small shrubs with revolute, tomentulose leaves, and it is endemic to the jalcas in the Cha-Chapoyas region (northern Perú) above 2,800 m. E. rosea includes shrubs with lanceolate to obovate-lanceolate leaves, largely glabrous (only pubescent adaxially along the mid vein), and it is restricted to the wet temperate forests of southern Chile (Valdivian forests). $E$. serrata includes procumbet shrubs with mostly obovate-cuneate leaves, often entirely glabrous (sometimes puberulous adaxially along the veins), and it is endemic to Patagonia in southern Chile and Argentina. In contrast, the new species includes profusely branched sub-shrubs with decumbent branching and slender twigs, and it is endemic to the dry forest in southern Bolivia at around 1,700 m. ii) Geographic sampling. One could propose that the new species is an allopatric population of any of the seven species. This would predict there are unsampled populations from any of the seven species across the geographic range of Escallonia. This is highly unlikely because other Escallonia species have been sampled thoroughly at intervening localities (Figure 5) and we have examined around 3,900 Escallonia herbarium specimens that indicate that the geographic range of the seven species is well sampled (Zapata, 2011). And iii) Statistical power. The sample size for E. callcottiae, E. gayana, and E. ledifolia is very low (Table 1), which lowers the statistical power of the method we used to diagnose morphological discontinuities (Zapata and Jiménez, 2012). Therefore the lack of evidence supporting a morphological discontinuity in these cases may just be a statistical artifact.

\section{TAXONOMIC TREATMENT}

Escallonia harrisii Zapata \& Villarroel, sp. nov. (Figure 6)

Type: BOLIVIA. SANTA CRUZ. Vallegrande. San Blas (abajo) y La Estancilla, $58 \mathrm{Km}$ de la ciudad de Vallegrande. $18^{\circ} 29^{\prime} \mathrm{S}, 63^{\circ} 59^{\prime} \mathrm{W}, 2200 \mathrm{~m}, 19$ November 1994 (fl), Vargas, I.G. 3673 (holotype: MO, isotypes: NY; USZ).

Paratype: BOLIVIA. ChUQUiSACA. $4 \mathrm{~km}$ de la comunidad de San Bartolo, sobre el camino a Nuevo Mundo, $19^{\circ} 39^{\prime} \mathrm{S}, 64^{\circ} 02^{\prime} \mathrm{W}, 1350 \mathrm{~m}, 14$ December 2013 (fl, fr), Villarroel et al. 2322 (UB; USZ).

Diagnosis: Decumbent branching, small narrowly elliptic leaves (14.5-19.7 x 1.6-3.7 mm), inflorescences with up to three flowers, flowers with red petals

Description: Perennial sub-shrub, to $2 \mathrm{~m}$ tall, profusely branched, branches decumbent, $1.9-1.0 \mathrm{~mm}$ diameter, angular to terete, outer bark scaly, grey, new growth branches angular, outer bark smooth, reddish, densely puberulent, hairs simple, white, 0.1-0.2 mm long. Leaves spiral; petiole 0.6-0.8 mm long; lamina oblanceolate, $14.5-19.7 \times 1.6-3.7 \mathrm{~mm}$, basally attenuate, apically acute, abaxially dull with scattered glands, minutely puberulent (simple hairs), adaxially lustrous green, glabrous; margin slightly serrate, glandular; secondary veins three to four pairs, brochidodromous. Inflorescences terminal, 1 to 3-flowered. Flowers hermaphrodite, pentamerous. Pedicels 2-4.7 mm long, 0.4-0.6 mm diameter, terete, densely puberulent (simple hairs). Ovary inferior, turbinate, $1.5-3 \times 2.4-3.8 \mathrm{~mm}$, puberulent. Calyx tube $0.5-0.7 \mathrm{~mm}$ long; lobes narrowly triangular-subulate, $5.8-10 \times 0.8-1.3 \mathrm{~mm}$, abaxially and adaxially puberulent, margin glandular, sparsely ciliate, sometimes recurved. Corolla actinomorphic, glabrous; petals red, spatulate, $6.7-7.9 \mathrm{~mm}$ long, $0.9-1.17 \mathrm{~mm}$ wide at base, $1.5-1.75 \mathrm{~mm}$ at the widest point, margin minutely crenulate. Stamens 5; filaments glabrous, terete, $4.2-4.9 \mathrm{~mm}$ long; anthers versatile, sub-basifixed, narrowly oblong 1.30 x $0.44 \mathrm{~mm}$. Style terete, 4.4-6.3 mm long. Stigma discoid. Disk flat. Fruit brown, turbinate, 3.10-4.12 x 3.41-4.70 mm, dehiscence septicidal. Seeds linear, $0.04 \mathrm{~mm}$ long, striate.

Additional Specimens Examined: BOLIVIA. ChuQuis aCA. Calvo. Serranía Incahuasi. 10-15 km from Muyupampa on road to Lagunillas, $19^{\circ} 21^{\prime} 51^{\prime \prime} \mathrm{S}, 63^{\circ} 50^{\prime} 09^{\prime \prime} \mathrm{W}, 1500 \mathrm{~m}, 8$ March 1998 (fl, fr), Wood et al. 13266 (K); CHUQuis ACA. Calvo. Serranía del Incahuasi, 10-15 km de Muyupampa sobre el camino a Lagunillas, $19^{\circ} 49^{\prime} 39^{\prime \prime} \mathrm{S}, 63^{\circ} 43^{\prime} 31^{\prime \prime} \mathrm{W}, 1580 \mathrm{~m}, 25$ March 2013 (fl, fr), Wood et al. 27640 (K; 
USZ); CHUQuis ACA. Calvo. Serranía Incahuasi, entre Muyupampa y Lagunillas, $19^{\circ} 49^{\prime} 38^{\prime \prime} \mathrm{S}, 63^{\circ} 43^{\prime}$ $30^{\prime \prime} \mathrm{W}, 1580$ m, 13 December 2013 (fl, fr), Villarroel et al. 2321 (UB; USZ); TARIJA. O'Connor. On w side of easternmost pass on road from Entre Rios to Palos Blancos, $21^{\circ} 25^{\prime} 28^{\prime \prime} \mathrm{S}, 63^{\circ} 54^{\prime} 47^{\prime \prime} \mathrm{W}, 1400$ m, 17 January 2001 (fr), Wood and Goyder 16822 (K).

Etymology: The specific epithet is in honor of Whitney R. Harris, who supported the center that now bears his name, the Whitney R. Harris World Ecology Center at the University of Missouri-St. Louis. Through the support provided by this center, several generations of biologists from throughout the world have been able to contribute to the study, understanding, and conservation of temperate and tropical ecosystems worldwide.

Phenology: Flowering and fruiting specimens have been collected between November and March. There are no observations yet on pollination or dispersal biology.

Distribution: Restricted to the south of Bolivia (Figure 7). Locally common.

Habitat: Plants of this species grow on rocky outcrops and ridges of red sandstone, mostly on steep slopes and summits between 1,300-2,200 m elevation. The dominant vegetation in the region where $E$. harrisii grows is dry forest on the slopes (i.e., Chaco Serrano forest) and semi-deciduous forests on the mountaintops (i.e., Tucumano Boliviano forest)

Conservation status: Although E. harrisii has been collected in few localities, it is locally common and it may not be threatened at present. Because it is restricted to the tropical dry forest, one of the most threatened tropical habits (Banda-R et al., 2016), it could become potentially vulnerable. However, more data and population-level studies are needed to assess the conservation status of this species. An IUCN category of Data Deficient (DD) is assigned, according to IUCN criteria (IUCN, 2012).

Affinities: Because we did not have access to good quality DNA, E. harrisii has not been included in a molecular phylogenetic study of Escallonia and its closest relatives are not known. Morphologically, $E$. harrisii displays similarities in leaf shape and flower number with E. callcottiae, E. gayana, E. ledifolia, $E$. myrtilloides, E. polifolia, E. rosea and E. serrata (Table 1). However, none of these species has decumbent branching, slender twigs and narrow oblanceolate leaves.

Ecologically, no other species of Escallonia has been found in sympatry with E. harrisii. Only $E$. millegrana, E. micrantha, E. pendula and E. herrerae grow at equivalent elevations and in similar habitats (i.e. dry forests in inter-Andean valleys). These four species are strikingly different in all morphological traits compared to E. harrisii (Table 1). Although E. millegrana also occurs in Bolivia, plants of this species are tall deciduous shrubs (up to $4 \mathrm{~m}$ ) with long leaves (up to $15 \mathrm{~cm}$ ), spines in young shoots, and inflorescences with around 850 flowers (Table 1).

\section{Key to the Escallonia species in the region where E. harrisii occurs}

1. Calyx lobes $>1 \mathrm{~mm}$

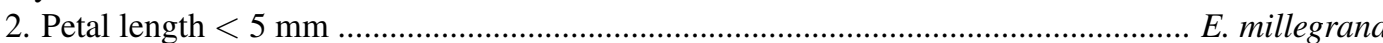

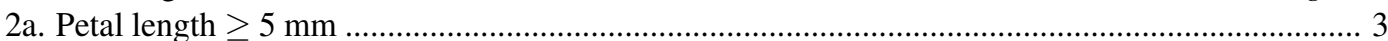

3. Pedicel width $>0.7 \mathrm{~mm}$ (stout, rigid) ............................................................. E. myrtilloides

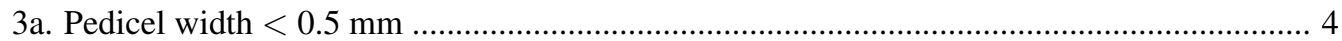

4. Lamina width at the widest point $11-30 \mathrm{~mm}$; petal length $13-17 \mathrm{~mm}$........ E. tucumanensis

4a. Lamina width at the widest point $<22 \mathrm{~mm}$; petal length $<12 \mathrm{~mm}$............................ 5

5. Lamina width at the widest point $<4 \mathrm{~mm}$................................................. E. harrisii

5a. Lamina width at the widest point $>7 \mathrm{~mm}$........................................... E. hypoglauca

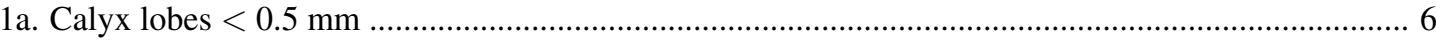

6. Petiole length $<10 \mathrm{~mm}$; lamina width at the widest point $<15 \mathrm{~mm}$......................................... 7

7. Lamina length $<50 \mathrm{~mm}$, oblongo-cuneate; petal length $\leq 6 \mathrm{~mm}$......................... E. resinosa

7a. Lamina length $>42 \mathrm{~mm}$, lanceolate; petal length $>6 \mathrm{~mm}$.............................. E. schreiteri

6a. Petiole length $\geq 10 \mathrm{~mm}$; lamina width at the widest point $\geq 15 \mathrm{~mm}$..................................... 8

8. Pedicel length 4-6 $\mathrm{mm}$; restricted to dry forests .................................................. E. reticulata

8a. Pedicel length 2-3 mm; restricted to cloud forests ................................................ E. paniculata

\section{ACKNOWLEDGMENTS}

We thank Peter F. Stevens and Elizabeth A. Kellogg for their constructive suggestions and valuable comments on earlier versions of the manuscript. We also thank the curators and collection managers of the herbaria cited for the use of their specimens, in particular to James Solomon (MO). Thanks to CAPES 
Table 1. Descriptive statistics. $\mathrm{N}=$ sample size, $\mathrm{m}=$ minimum, $\mathrm{Me}=$ mean, $\mathrm{M}=$ maximum, $\mathrm{LL}=$ leaf length, $\mathrm{LW}=$ leaf width, $\mathrm{FN}=$ flower number, $\mathrm{E}=$ elevation. New species in bold. *Species occurring in Bolivia.

\begin{tabular}{|c|c|c|c|c|c|c|c|c|c|c|c|c|}
\hline & $\mathrm{N}$ & $\mathrm{mLL}$ & MeLL & MLL & $\mathrm{mLW}$ & MeLW & MLW & $\mathrm{mFN}$ & MeFN & MFN & $\mathrm{mE}$ & ME \\
\hline E. alpina & 40 & 9.2 & 16.6 & 26.5 & 4 & 7.0 & 9.8 & 1 & 8.1 & 14 & 20 & 2300 \\
\hline E. angustifolia & 13 & 39.5 & 54.6 & 74 & 5 & 11 & 17 & 16 & 70.3 & 155 & 1600 & 3280 \\
\hline E. bifida & 36 & 41.7 & 55.9 & 79 & 13.3 & 17.4 & 23.3 & 25 & 83.1 & 150 & 70 & 2300 \\
\hline E. callcottiae & 6 & 21.7 & 29.2 & 42.3 & 9.7 & 13 & 21.7 & 12 & 23.7 & 55 & 40 & 800 \\
\hline E. chlorophylla & 13 & 37.3 & 47.6 & 56.7 & 12.6 & 17.6 & 23.4 & 27 & 42.1 & 60 & 0 & 1312 \\
\hline E. cordobensis & 11 & 29.7 & 40.6 & 53.5 & 6 & 7.9 & 10.9 & 7 & 12.7 & 22 & 1000 & 2400 \\
\hline E. discolor & 5 & 48.7 & 59.0 & 76.7 & 17.7 & 20.9 & 23.3 & 65 & 103 & 150 & 2500 & 3300 \\
\hline E. farinacea & 18 & 35 & 48.6 & 62.3 & 10 & 14.6 & 18.3 & 6 & 13.9 & 22 & 812 & 1810 \\
\hline E. florida & 10 & 16 & 18.8 & 23 & 3 & 3.7 & 6 & 10 & 31.3 & 61 & 624 & 2000 \\
\hline E. gayana & 7 & 13.3 & 16.9 & 21.7 & 4.3 & 5.6 & 7.1 & 28 & 48 & 100 & 100 & 800 \\
\hline E. harrisii & 6 & 14.5 & 16.8 & 19.7 & 1.6 & 2.8 & 3.7 & 1 & 1.8 & 3 & 1350 & 2200 \\
\hline E. herrerae & 8 & 103.7 & 152.1 & 174.3 & 24.3 & 35 & 46 & 115 & 157 & 250 & 1800 & 3450 \\
\hline E. hispida & 8 & 35 & 47.2 & 55.8 & 16.2 & 20 & 22.2 & 16 & 20.3 & 34 & 600 & 1500 \\
\hline *E. hypoglauca & 24 & 18 & 30.3 & 48.3 & 7.3 & 13.3 & 22.3 & 7 & 10.9 & 24 & 2200 & 3500 \\
\hline E. illinita & 25 & 37.7 & 45.8 & 58.7 & 8.3 & 16.4 & 21.7 & 22 & 49.5 & 150 & 40 & 2650 \\
\hline E. laevis & 27 & 20.3 & 37 & 57.4 & 9.6 & 13.8 & 21 & 7 & 14 & 30 & 0 & 2750 \\
\hline E. ledifolia & 10 & 27.7 & 35.9 & 43 & 5 & 7.4 & 9.7 & 2 & 5.6 & 8 & 950 & 1150 \\
\hline E. leucantha & 14 & 15.7 & 22.7 & 31 & 5.3 & 8.3 & 11 & 33 & 61.2 & 80 & 50 & 707 \\
\hline E. megapotamica & 29 & 21 & 31.2 & 48 & 5.5 & 8.9 & 16 & 19 & 49.11 & 95 & 30 & 1000 \\
\hline E. micrantha & 11 & 88.3 & 118.8 & 142.3 & 23 & 32.4 & 43.3 & 800 & 881.8 & 950 & 1850 & 2500 \\
\hline *E. millegrana & 21 & 73.3 & 104.8 & 146.3 & 22.5 & 32.5 & 46 & 700 & 835.7 & 950 & 1228 & 2950 \\
\hline${ }^{*}$ E. myrtilloides & 56 & 6.7 & 14.4 & 30.3 & 3.8 & 7.1 & 18 & 1 & 1 & 1 & 2351 & 4100 \\
\hline E. myrtoidea & 15 & 31.7 & 45 & 72 & 15.3 & 20.9 & 26 & 35 & 73.8 & 115 & 120 & 2000 \\
\hline E. obtusissima & 6 & 52 & 61.2 & 69.3 & 19 & 22.7 & 27.7 & 27 & 32.8 & 45 & 800 & 1200 \\
\hline${ }^{*}$ E. paniculata & 66 & 40.7 & 75.7 & 112 & 16.3 & 24 & 37 & 40 & 148.9 & 800 & 1200 & 3492 \\
\hline E. pendula & 30 & 116.7 & 175.4 & 217.7 & 22.3 & 38.3 & 55.7 & 80 & 169.3 & 280 & 1300 & 3100 \\
\hline E. petrophila & 8 & 55.8 & 84.6 & 98.7 & 20.9 & 25.9 & 29 & 5 & 7 & 11 & 800 & 1131 \\
\hline E. piurensis & 12 & 24 & 36.5 & 44.7 & 9.7 & 11.4 & 13.7 & 20 & 44.9 & 75 & 2500 & 3300 \\
\hline E. polifolia & 9 & 13.8 & 17.6 & 19.5 & 2.3 & 2.8 & 3.8 & 1 & 1 & 1 & 2900 & 3500 \\
\hline E. pulverulenta & 25 & 41.9 & 54.6 & 72.9 & 17.3 & 26.5 & 37 & 140 & 171.5 & 200 & 0 & 1200 \\
\hline${ }^{*}$ E. resinosa & 46 & 20.7 & 34.1 & 52.7 & 5.7 & 8.6 & 13 & 10 & 56.4 & 130 & 2200 & 3776 \\
\hline${ }^{*}$ E. reticulata & 21 & 55.7 & 68.7 & 80 & 15 & 23.7 & 28.3 & 25 & 55.8 & 100 & 1300 & 2400 \\
\hline E. revoluta & 21 & 31.7 & 39.1 & 49.3 & 12.8 & 18.7 & 25.7 & 27 & 75.3 & 180 & 1 & 1642 \\
\hline E. rosea & 30 & 15 & 33.5 & 51 & 5 & 12.8 & 24.3 & 5 & 16.7 & 55 & 185 & 1662 \\
\hline E. rubra & 46 & 21.7 & 36.6 & 58.3 & 6.3 & 16.7 & 32 & 5 & 15.5 & 45 & 0 & 1605 \\
\hline${ }^{*}$ E. schreiteri & 18 & 42.3 & 56.6 & 74 & 8.3 & 11.1 & 14.7 & 20 & 42.6 & 60 & 1600 & 2954 \\
\hline E. serrata & 20 & 8.2 & 14.4 & 21.2 & 4.3 & 6.6 & 9.5 & 1 & 1 & 1 & 5 & 400 \\
\hline${ }^{*}$ E. tucumanensis & 18 & 31.7 & 50.5 & 76 & 11 & 18.3 & 30.7 & 6 & 14.2 & 30 & 800 & 2800 \\
\hline E. virgata & 20 & 9.5 & 11.7 & 14.7 & 3.5 & 4.5 & 5.7 & 6 & 13.1 & 28 & 61 & 3000 \\
\hline
\end{tabular}

(Coordenação de Aperfeiçoamento de Pessoal de Nivel Superior) and the University of Brasilia (UNB) for a doctoral scholarship to DV. We are grateful to Barbara Alongi for preparing the beautiful illustration of E. harrisii.

\section{REFERENCES}

APG (2016). An update of the Angiosperm Phylogeny Group classification for the orders and families of flowering plants: APG IV. Botanical Journal of the Linnean Society, 181:1-20.

Banda-R, K., Delgado-Salinas, A., Dexter, K. G., Linares-Palomino, R., Oliveira-Filho, A., Prado, D., Pullan, M., Quintana, C., Riina, R., Rodriguez M, G. M., Weintritt, J., Acevedo-Rodriguez, P., Adarve, J., Alvarez, E., Aranguren B, A., Arteaga, J. C., Aymard, G., Castano, A., Ceballos-Mago, N., Cogollo, A., Cuadros, H., Delgado, F., Devia, W., Duenas, H., Fajardo, L., Fernandez, A., Fernandez, M. A., Franklin, J., Freid, E. H., Galetti, L. A., Gonto, R., Gonzalez-M, R., Graveson, R., Helmer, E. H., Idarraga, A., Lopez, R., Marcano-Vega, H., Martinez, O. G., Maturo, H. M., McDonald, M., McLaren, K., Melo, O., Mijares, F., Mogni, V., Molina, D., Moreno, N. d. P., Nassar, J. M., Neves, D. M., Oakley, L. J., Oatham, M., Olvera-Luna, A. R., Pezzini, F. F., Dominguez, O. J. R., Rios, M. E., Rivera, O., Rodriguez, N., Rojas, A., Sarkinen, T., Sanchez, R., Smith, M., Vargas, C., Villanueva, B., and Pennington, R. T. (2016). Plant diversity patterns in neotropical dry forests and their conservation implications. Science (New York, N.Y.), 353(6306):1383-1387.

Beaulieu, J. M. and O'Meara, B. C. (2018). Can we build it? Yes we can, but should we use it? Assessing the quality and value of a very large phylogeny of campanulid angiosperms. American Journal of Botany, 88:163-16.

de Queiroz, K. (1998). The General Lineage Concept of Species, Species Criteria, and the Process. In Harrison, R. G. and Berlocher, S. H., editors, Endless forms: Species and speciation, pages 57-75. New York.

De Queiroz, K. (2007). Species concepts and species delimitation. Systematic Biology, 56(6):879-886.

Denaeghel, H. E. R., Van Laere, K., Leus, L., Lootens, P., Van Huylenbroeck, J., and Van Labeke, M.-C. (2018). The Variable Effect of Polyploidization on the Phenotype in Escallonia. Frontiers in Plant Science, 9:36-17. 
Hanson, L., Brown, R. L., Boyd, A., Johnson, M. A. T., and Bennett, M. D. (2003). First Nuclear DNA C-values for 28 Angiosperm Genera. Annals of Botany, 91:31-38.

IUCN (2012). IUCN Red List Categories and Criteria, Version 3.1. IUCN, Gland, Switzerland, Cambridge, United Kingdom, 2 edition.

Kausel, E. (1953). Revisión del género Escallonia en Chile. Darwiniana, 10:169-255.

Myers, N., Mittermeier, R. A., Mittermeier, C. G., da Fonseca, G. A., and Kent, J. (2000). Biodiversity hotspots for conservation priorities. Nature, 403:853-858.

R Core Team (2016). R: A Language and Environment for Statistical Computing. R Foundation for Statistical Computing, Vienna, Austria.

Sanders, R. W., Stuessy, T. F., and Rodriguez, R. (1983). Chromosome numbers of the flora of the Juan Fernandez Islands. American Journal of Botany, 70(6):799.

Särkinen, T., Pennington, R. T., Lavin, M., Simon, M. F., and Hughes, C. E. (2011). Evolutionary islands in the Andes: persistence and isolation explain high endemism in Andean dry tropical forests. Journal of Biogeography, 39(5):884-900.

Sede, S. M. and Denham, S. S. (2018). Taxonomic Revision of Escallonia (Escalloniaceae) in Argentina. Systematic Botany, 43(1):364-396.

Sede, S. M., Dürnhöfer, S. I., Morello, S., and Zapata, F. (2013). Phylogenetics of Escallonia (Escalloniaceae) based on plastid DNA sequence data. 173(3):442-451.

Sleumer, H. O. (1968). Die Gattung Escallonia. Verhandelingen der Koninklijke Nederlandse Akademie van Wetenschappen, Afd. Natuurkunde, pages 1-149.

Tank, D. C. and Donoghue, M. J. (2010). Phylogeny and phylogenetic nomenclature of the Campanulidae based on an expanded sample of genes and taxa. Systematic Botany, 35(2):425-441.

Zapata, F. (2011). Phylogenetics and diversification of Escallonia (Escalloniaceae). PhD thesis, University of Missouri, St. Louis.

Zapata, F. (2013). A multilocus phylogenetic analysis of Escallonia (Escalloniaceae): diversification in montane South America. American Journal of Botany, 100(3):526-545.

Zapata, F. and Jiménez, I. (2012). Species delimitation: inferring gaps in morphology across geography. Systematic Biology, 61(2):179-194.

Zielinski, Q. B. (1955). Escallonia: the genus and its chromosomes. Botanical Gazette, pages 166-172. 

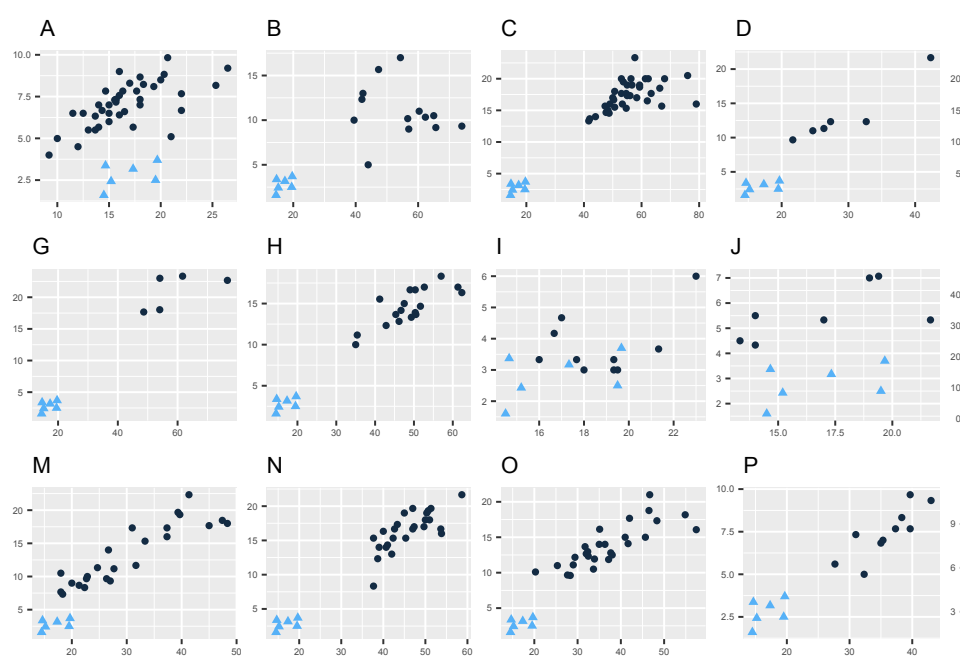

$\mathrm{P}$
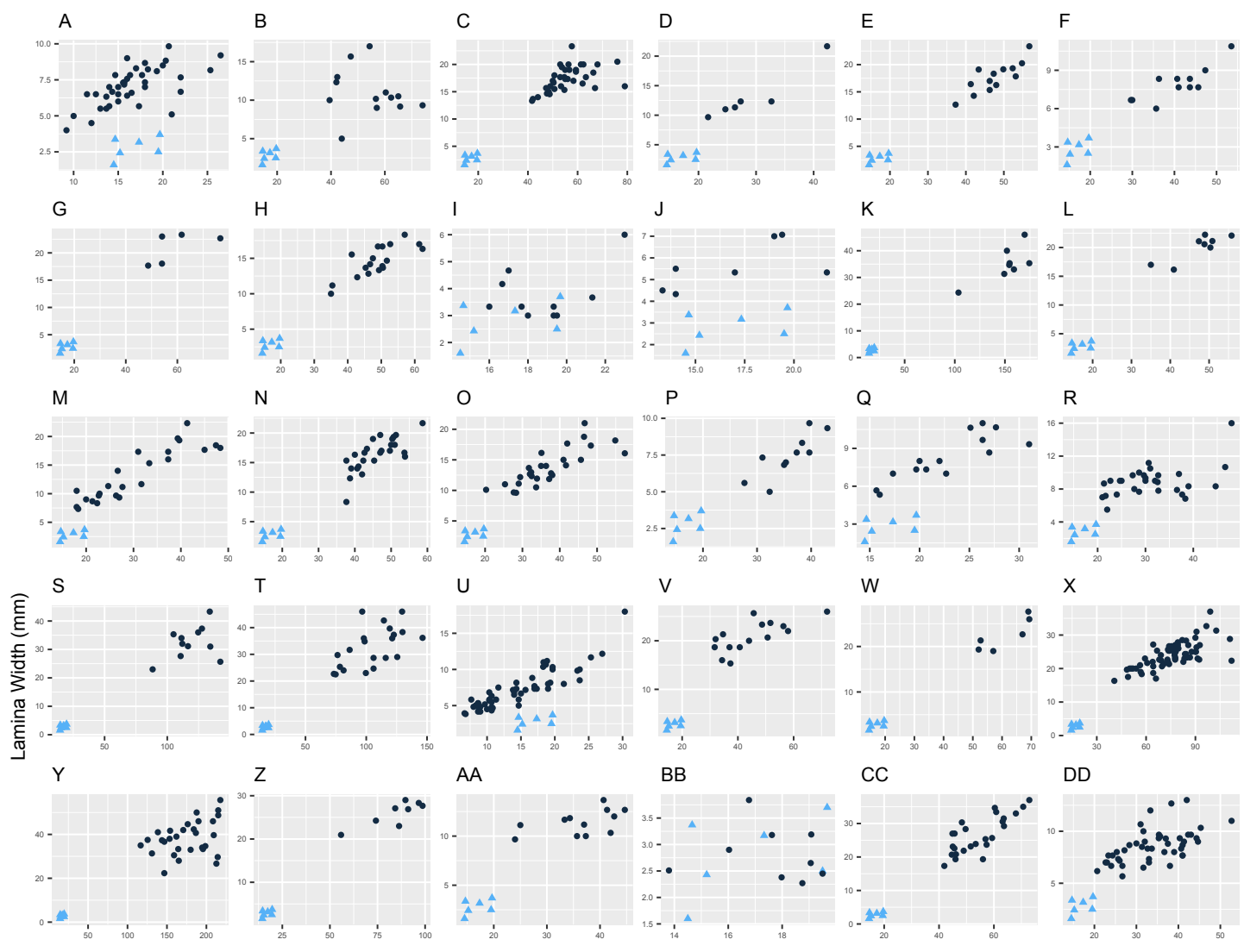

U
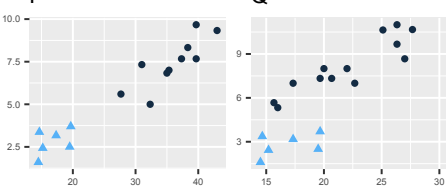

$\mathrm{R}$
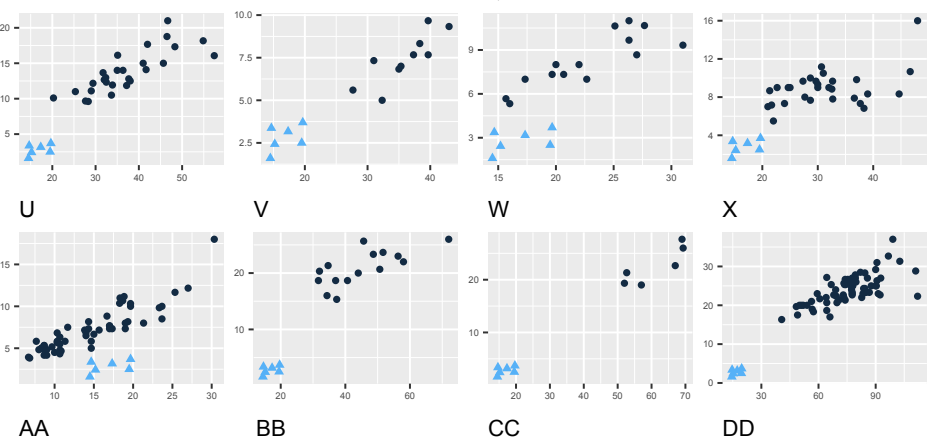

$\mathrm{CC}$

DD
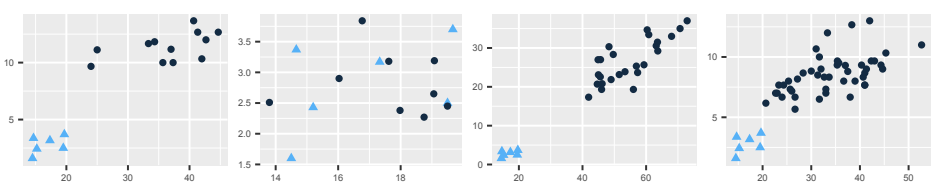

$\mathrm{EE}$

GG

$\mathrm{HH}$

JJ
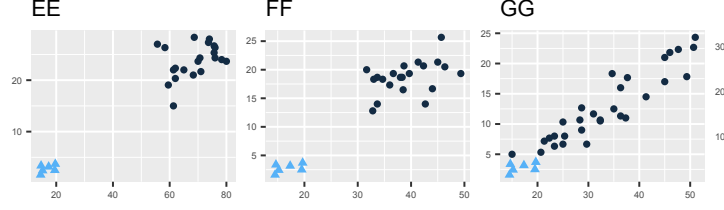

II
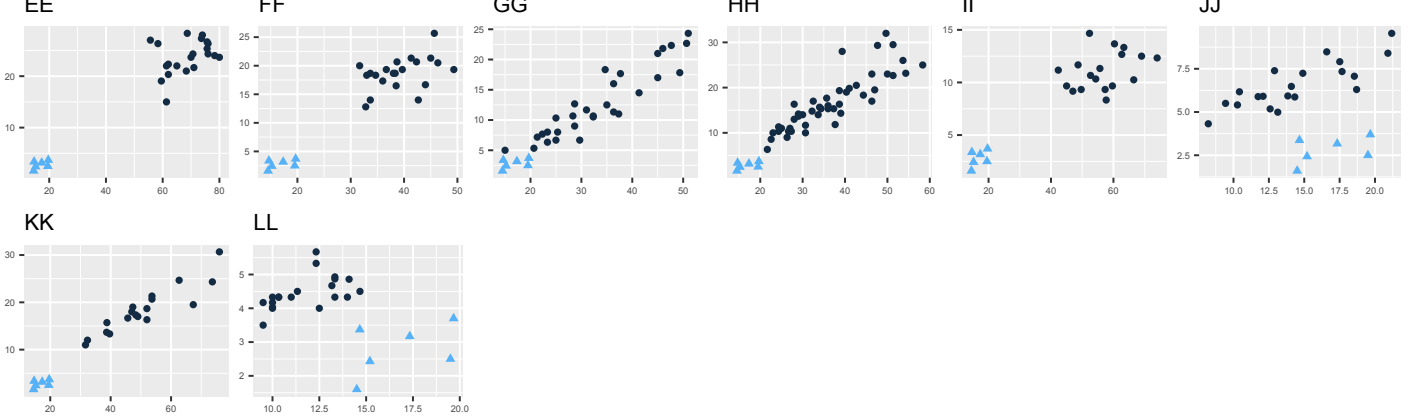

Lamina Length (mm)

Figure 1. Variation in leaf morphology in Escallonia. Each panel corresponds to the pairwise comparison between a currently known species (dark circles) and the new species (E. harrisii; light triangles) for lamina length (X-axis) and lamina width (Y-axis). E. harrisii vs. A. E. alpina; B. E. angustifolia; C. E. bifida; D. E. callcottiae; E. E. chlorophylla; F. E. cordobensis; G. E. discolor; H. E. farinacea; I. E. florida; J. E. gayana; K. E. herrerae; L. E. hispida; M. E. hypoglauca; N. E. illinita; O. E. laevis; P. E. ledifolia; Q. E. leucantha; R. E. megapotamica; S. E. micrantha; T. E. millegrana; U. E. myrtilloides; V. E. myrtoidea; W. E. obtusissima; X. E. paniculata; Y. E. pendula; Z. E. petrophila; AA. E. piurensis; BB. E. polifolia; CC. E. pulverulenta; DD. E. resinosa; EE. E. reticulata; FF. E. revoluta; GG. E. rosea; HH. E. rubra; II. E. schreiteri; JJ. E. serrata; KK. E. tucumanensis; LL. E. virgata. 


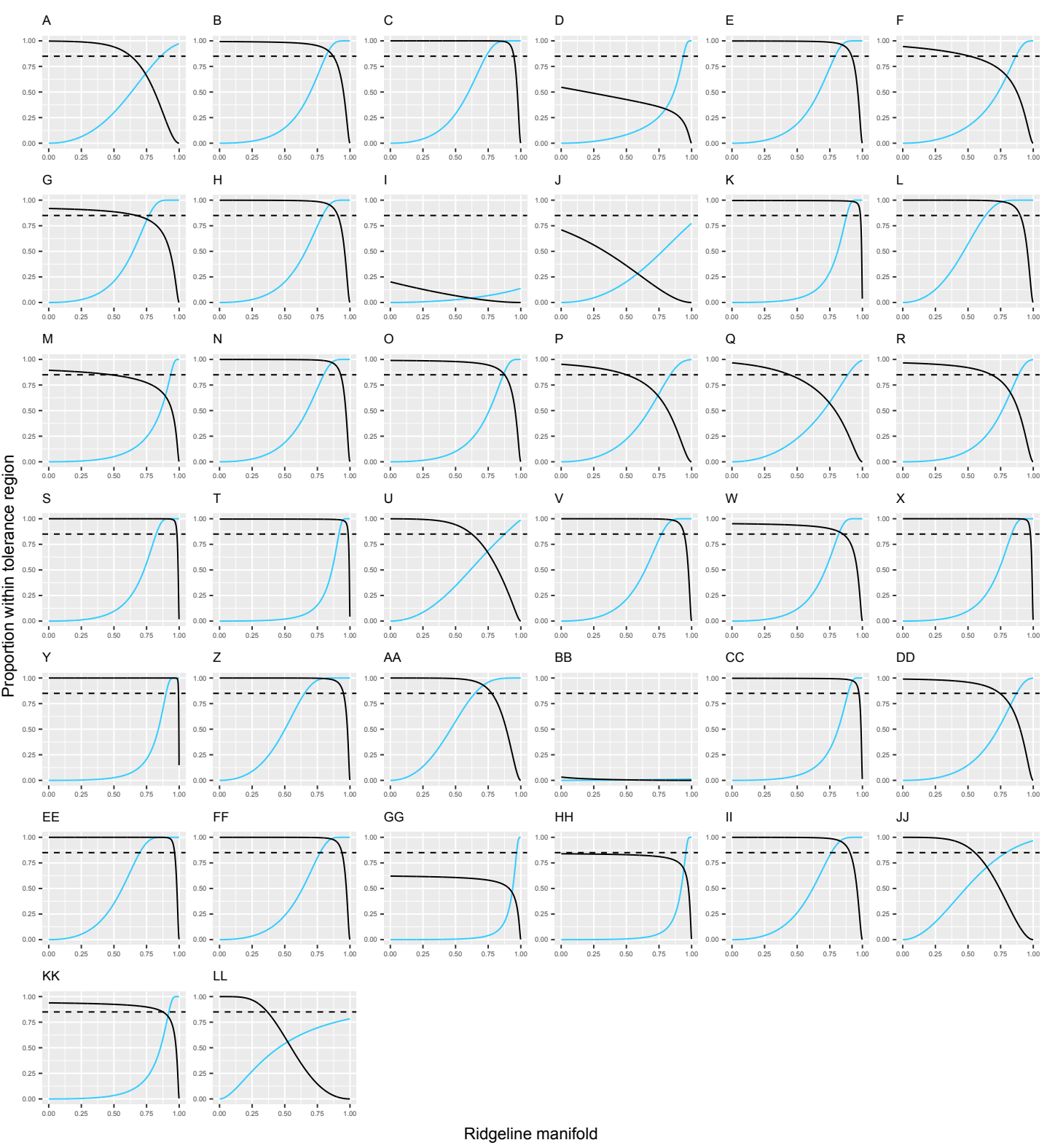

Figure 2. Discontinuity in leaf morphology in Escallonia. Each panel corresponds to the pairwise comparison between a currently known species (dark continuous line) and the new species (E. harrisii; light continuous line). The continuous lines show the estimated proportion (Y-axis) covered with confidence $\gamma=0.90$ by the tolerance regions sharing a single point along the ridgeline manifold (X-axis). The ridgeline manifold is the curve that includes all the critical points of the bivariate normal mixture describing the morphological variation implied by each pairwise comparison in Figure 1. The ridgeline manifold ranges from zero, the bivariate mean of the new species (E. harrisii), to one, the bivariate mean of the currently known species. The dashed line marks proportion $\beta=0.85$ (one minus threshold 0.15 ) below which overlap indicates lack of a morphological discontinuity. E. harrisii vs. A. E. alpina; B. E. angustifolia; C. E. bifida; D. E. callcottiae; E. E. chlorophylla; F. E. cordobensis; G. E. discolor; H. E. farinacea; I. E. florida; J. E. gayana; K. E. herrerae; L. E. hispida; M. E. hypoglauca; N. E. illinita; O. E. laevis; P. E. ledifolia; Q. E. leucantha; R. E. megapotamica; S. E. micrantha; T. E. millegrana; U. E. myrtilloides; V. E. myrtoidea; W. E. obtusissima; X. E. paniculata; Y. E. pendula; Z. E. petrophila; AA. E. piurensis; BB. E. polifolia; CC. E. pulverulenta; DD. E. resinosa; EE. E. reticulata; FF. E. revoluta; GG. E. rosea; HH. E. rubra; II. E. schreiteri; JJ. E. serrata; KK. E. tucumanensis; LL. E. virgata. 


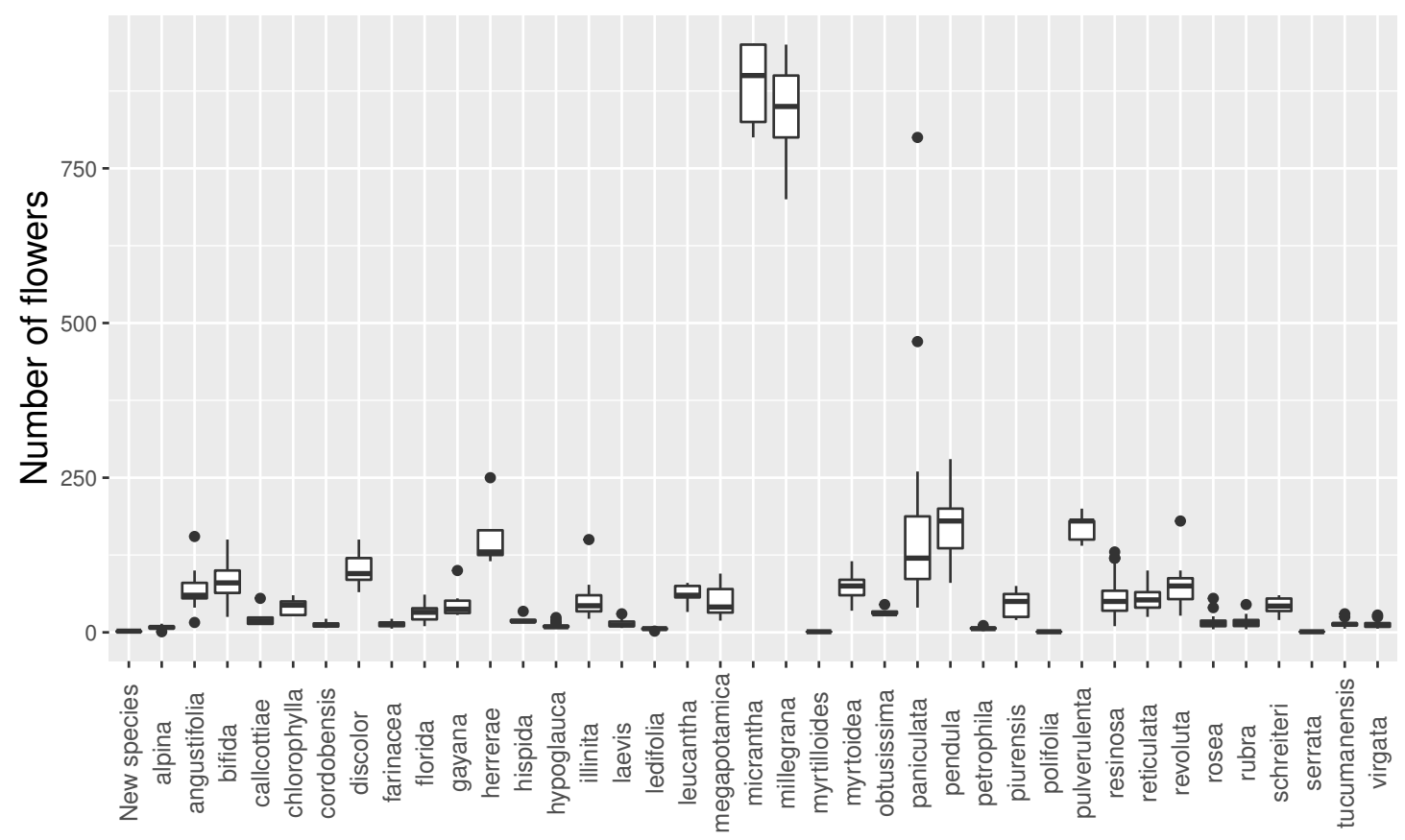

Figure 3. Variation in flower number in Escallonia. New species (E. harrisii) at the left. 


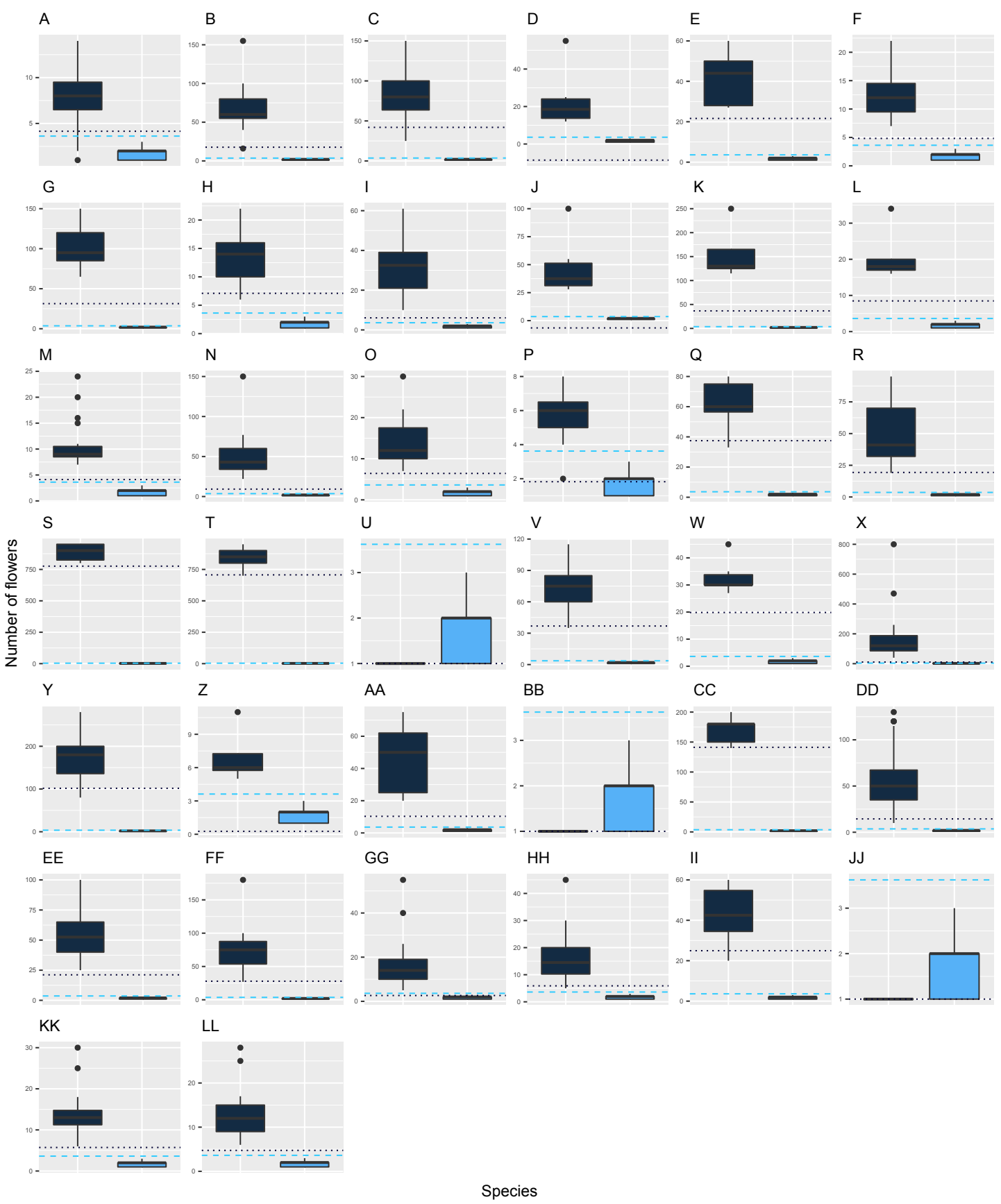

Figure 4. Discontinuity in flower number in Escallonia. Each panel corresponds to the pairwise comparison between a currently known species (dark color) and the new species (E. harrisii; light color). The dotted and dashed lines estimate with confidence $\gamma=0.90$ the limits of one-tailed tolerance regions encompassing a proportion $\beta=0.85$ (one minus threshold 0.15 ) of the currently known and new species, respectively. E. harrisii vs. A. E. alpina; B. E. angustifolia; C. E. bifida; D. E. callcottiae; E. E. chlorophylla; F. E. cordobensis; G. E. discolor; H. E. farinacea; I. E. florida; J. E. gayana; K. E. herrerae; L. E. hispida; M. E. hypoglauca; N. E. illinita; O. E. laevis; P. E. ledifolia; Q. E. leucantha; R. E. megapotamica; S. E. micrantha; T. E. millegrana; U. E. myrtilloides; V. E. myrtoidea; W. E. obtusissima; X. E. paniculata; Y. E. pendula; Z. E. petrophila; AA. E. piurensis; BB. E. polifolia; CC. E. pulverulenta; DD. E. resinosa; EE. E. reticulata; FF. E. revoluta; GG. E. rosea; HH. E. rubra; II. E. schreiteri; JJ. E. serrata; KK. E. tucumanensis; LL. E. virgata. 


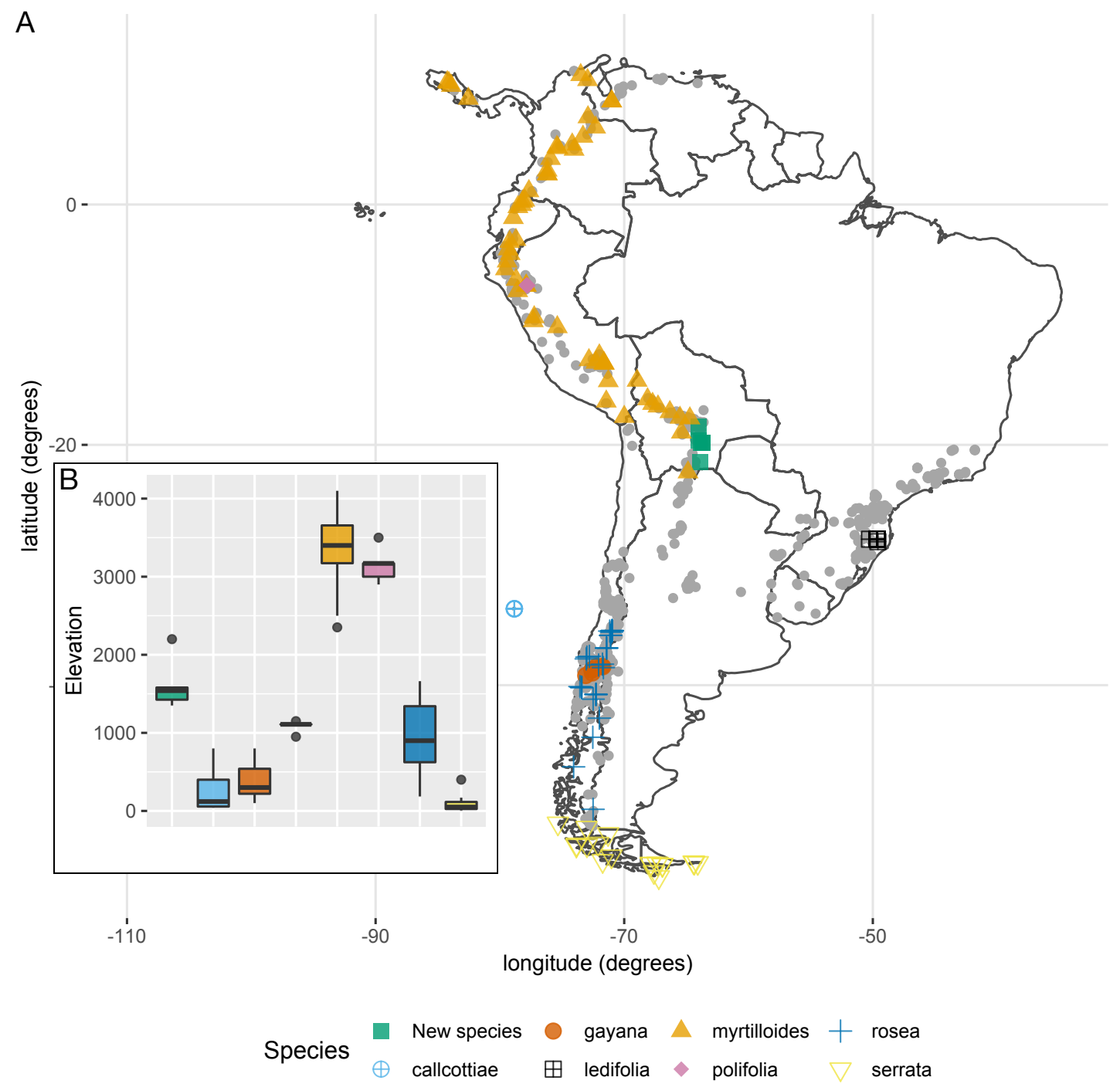

Figure 5. A. Geographic distribution of species lacking support for morphological discontinuities $v s$ the new species (E. harrisii). Grey points correspond to all other Escallonia species. B. Elevation range of species lacking support for morphological discontinuities $v$ s. the new species (E. harrisii). 

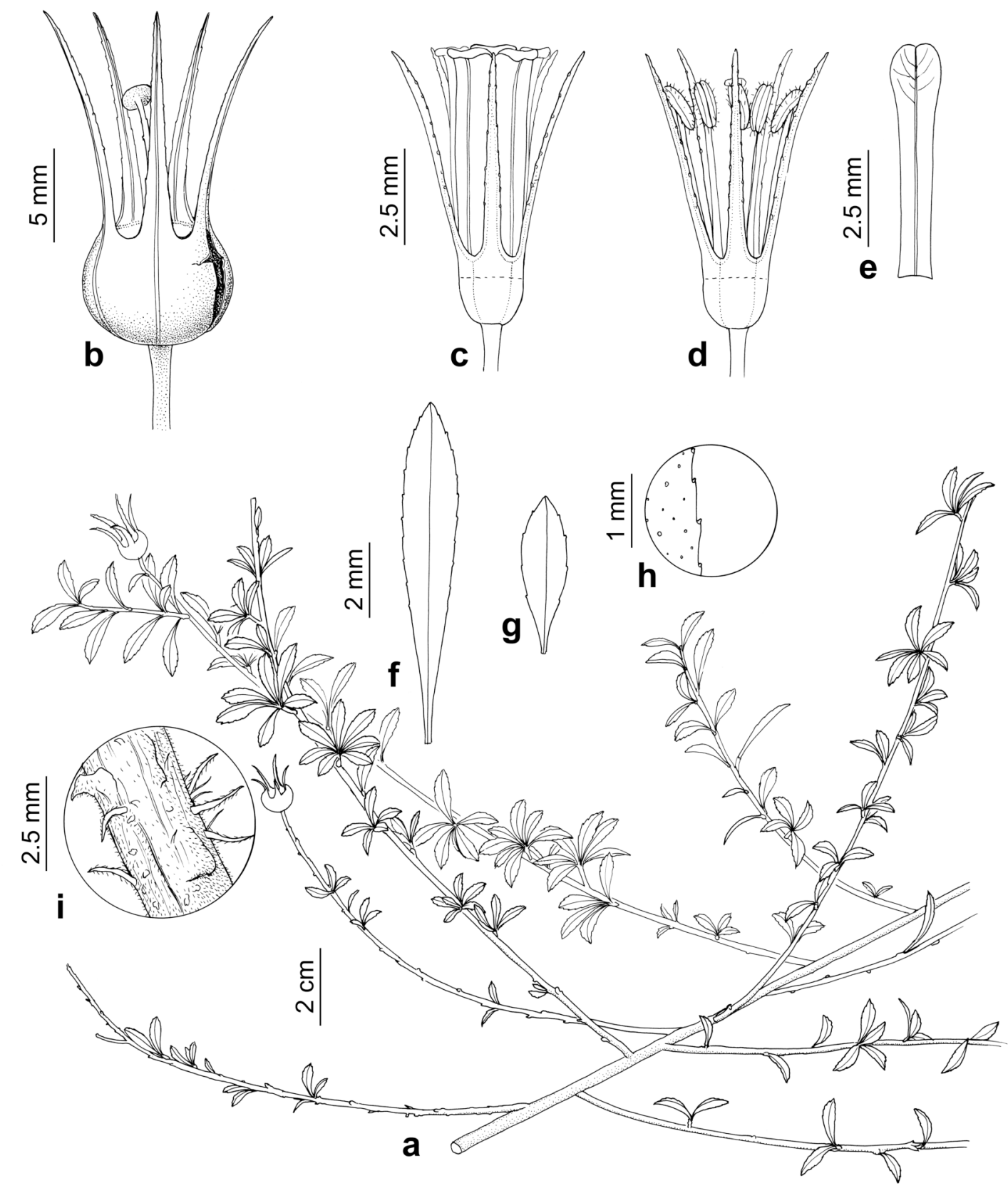

Figure 6. Escallonia harrisii. Zapata \& Villarroel. a. Habit, b. Fruit, c. Flower, d. Flower with petals removed, e. Petal, f. Mature leaf, g. Young leaf, h. Detail of leaf margin, i. Detail of outer bark in mature shoot. Illustration by B. Alongi based on Vargas, I.G. 3673 (MO) and Wood et al. 13266 (K). 


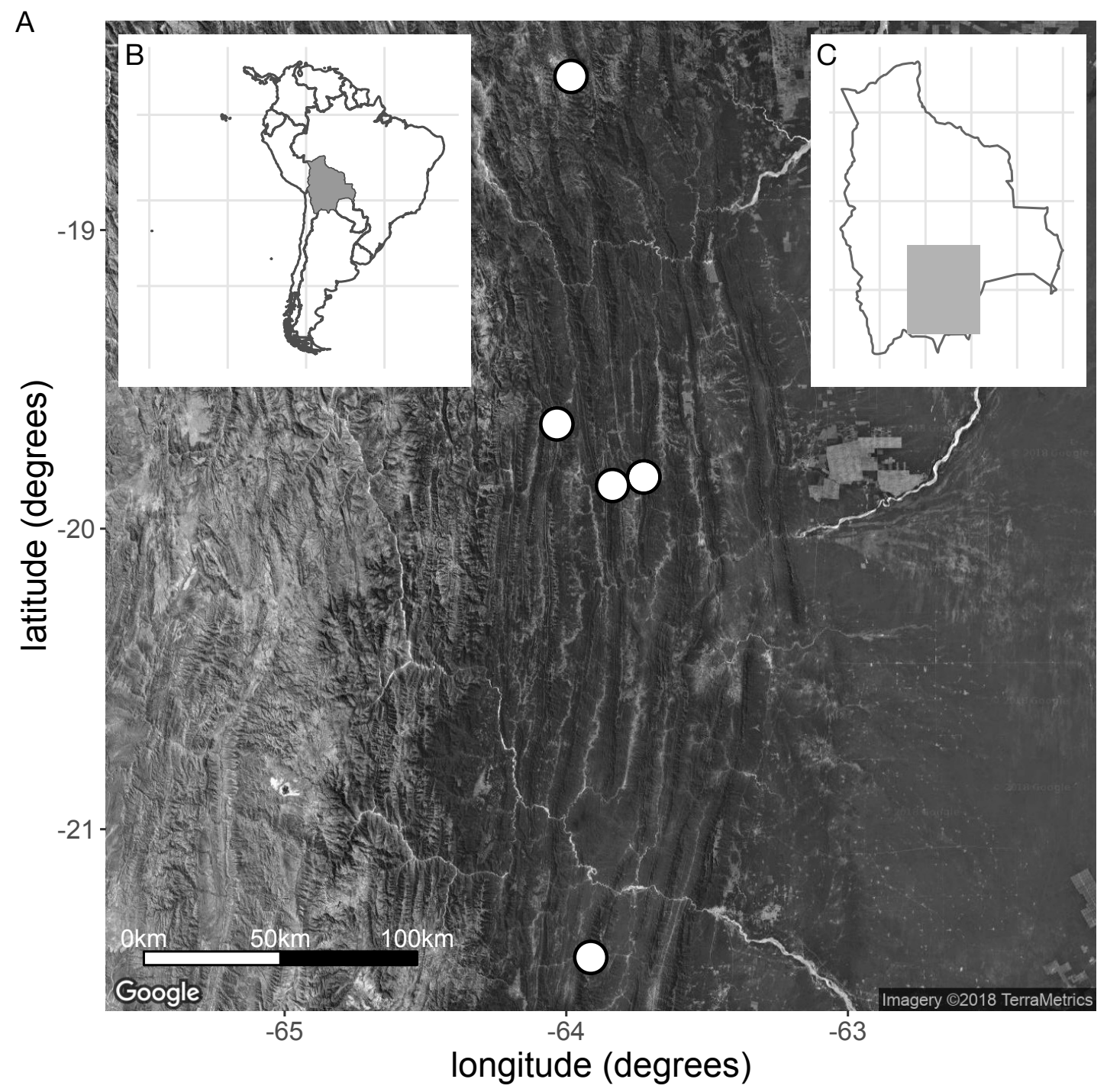

Figure 7. A. Collection sites of the new species E. harrisii. B. Map of South America, Bolivia shaded. C. Map of Bolivia, area of A. shaded. (Map Credit: (C) 2018 Google, TerraMetrics) 